\title{
MYCOLOGICAL QUALITY OF IMPORTED FROZEN LIVER FOR HUMAN CONSUMPTION
}

\author{
Nader Y. Moustafa ; Amgad A.Mowad ${ }^{* *}$ and Ibrahim A. Gaballah* \\ Food Control Dept. Fac. of Vet. Med., Kafrelsheikh Univ., Egypt. \\ ** Bacteriology, Mycology and Immunology Dept. Fac. of Vet. Med., \\ Kafrelsheikh Univ., Egypt
}

\begin{abstract}
A total of 100 samples of imported frozen liver were randomly collected from different markets at El-Gharbiah governorate, Egypt.The samples were examined for detection of molds and determination of aflatoxins produced by their aflatoxigenic strains. The results showed that $33 \%$ of the samples were contaminated with different mold species and the average mold count $(/ \mathrm{g})$ was $3.8 \times 10^{4} \pm$ $8.2 \times 10^{3} \mathrm{~g}$. Genus Aspergilluswasthe predominant species detected in the positive samples $(54.55 \%)$ followed by Genus Penicillium(51.52\%). The positive samples were examined for extraction and estimation of aflatoxins B1, B2, G1 and G2 using $H P L C$. The results indicated that aflatoxins $B 1, B 2, G 1$ and $G 2$ were detected in 24.2, 21.2, 18.2 and $15.1 \%$ of such liver samples, respectively. These results showed that imported frozen liver can represent a potential source of variousmold species and their toxinsconstituting, at times, a public health hazard.
\end{abstract}

\section{INTRODUCTION}

Beef liver is considered as an excellent source of high quality animal protein, vitamins, and fat that keep our body health, however, liver products presented high-risk food as they are highly nutritious and serve as an ideal medium for microbial contamination especially mold growth (Kalhy, 2011). This contamination is mainly related to poor 
hygienic practices by food handlers and instruments such as cutting boards, machines, and all other related materials used for preparation of liver to sell to consumers.

The presence of mold in the food sample is due to its disperse in the form of spores which are abundant in the environment and can be introduced through dust and soil (Apinis, 2003). Their presence in these food samples is a serious public health concern as these fungi may be associated with the production of mycotoxins (Anthony et al., 2009).

Mycotoxins are recognized as naturally occurring secondary metabolites, produced in meat products by direct growth of toxigenic molds such as Aspergillus, Penicillium and Fusarium or from residue in animal feed (Iqbal et al., 2013)(Bailly and Guerre, 2009); (Fazekas et al., 2005).Aflatoxins especially AFB1, AFB2, AFG1 and AFG2 are secondary metabolites ofAspergillusflavusand Aspergillusparasiticus which considered the most serious threat to public health due to their carcinogenic and hepatotoxic, teratogenic and mutagenic effect in human and animal (Maqbool et al., 2004). Therefore, the aim of the present study was to throw a light on the incidence of molds and their aflatoxinsin imported frozen livers.

\section{MATERIAL AND METHODS}

\section{Collection of samples}

One hundred random samples of imported frozen livers were collected from different markets at El-Gharbia governorate. The collected samples were transferred directly to the laboratory in their packages. The samples were immediately examined for the isolation and identification of molds and aflatoxins. 
2. Preparation of samples (ICMSF, 1996):

To 10 grams of the liver sample, $90 \mathrm{ml}$ of sterile peptone water were added and thoroughly mixed using sterile blender for 1.5 minutes, from which tenfold serial dilutions were prepared. The prepared samples were subjected to the following examinations.

\section{Determination of total mold count}

It was carried out according to the technique recommended by (ICMSF, 1996).

\section{Identification ofisolated molds:}

Identification of mold genera and species was carried out according to Raper and Fennel (1965) and Samson (1979) for genus Aspergillus, ARX (1967); Raper and Thom (1969); Samson et al. (1976) and Zycha et al. (1969) for the other mold genera. The isolated mold strains were subcultured on malt extract agar and Czapek-Dox agar for qualitative estaimtion. The plates were incubated at $25^{\circ} \mathrm{C}$ for $1-2$ days or more whenever was necessary.

\section{Screening of Toxigenicity test for Aspergillusflavus strains:}

The technique recommended by Hara et al. (1994) was performed for detection the toxigenic strains of A. flavus.

\section{Qualitative and quantitative estimation of aflatoxins:}

The stock standard solutions of B1, B2, G1 and G2 were prepared by dissolving the solid standard in benzene: acetonitrile $(98: 2, \mathrm{v} / \mathrm{v})$. The precise concentration was measured in Shimadzu UV-1601 PC spectrophotometer, Shimadzu Scientific Instruments, Japan, as described by $A O A C$ (2000). 
The prepared samples were analyzed using a validated method by reversed-phase HPLC separation and fluorescence detection after postcolumn derivatization (Shundo and Sabino, 2006). Then the mixture was filtered through Whatman No 1 filter paper. After filtration, the extract $(5 \mathrm{ml})$ was diluted with water $(75 \mathrm{ml})$. The immunoaffinity column was connected to the vacuum manifold, and the reservoir was attached to the immunoaffinity column. A number of $40 \mathrm{ml}$ of diluted sample extract were added to the reservoir and passed through the immunoaffinity column at a flow rate of ca. $3 \mathrm{ml} / \mathrm{min}$ (ca. $1 \mathrm{drop} / \mathrm{s}$; gravity). Do not exceed a flow rate of $5 \mathrm{ml} / \mathrm{min}$. The column was washed twice with $10 \mathrm{ml}$ water at a flow rate of maximum $5 \mathrm{ml} / \mathrm{min}$ and dried by applying little vacuum for 5-10 seconds. Finally, aflatoxin was eluted with $0.5 \mathrm{ml}$ methanol and passed through by gravity. The eluate was collected in a vial. After 1 minute, a second portion of $0.5 \mathrm{ml}$ methanol was applied. Most of the applied elution solvent was collected by pressing air or vacuum through. The extract was evaporated to dryness under a nitrogen stream at $50^{\circ} \mathrm{C}$ and reconstituted with $250 \mu \mathrm{L}$ with methanol: water (2:3), v/v. Aflatoxin was subjected to light degradation, thus it was necessary to protect the work from light by using amber vials. As a result, the method was found to be fit-for-purpose for the determination of this aflatoxin in the examined samples at levels of 1.0 $\mu \mathrm{g} \mathrm{kg-1}$ and above.

The quantification of aflatoxin was performed by measuring its peak areas at each retention time and comparing it with the calibration curve (Galvano et al., 2001). The performance of the method, aflatoxin recovery and effectiveness of the cleanup procedure, was evaluated by the samples spiked with this aflatoxin. 


\section{RESULTS}

Table (1): Statistical analytical results of total mould count/ g of examined frozen liver samples.

\begin{tabular}{|c|c|c|c|c|c|}
\hline $\begin{array}{c}\text { No. of examined } \\
\text { samples }\end{array}$ & \multicolumn{2}{|c|}{ +ve samples } & \multirow{2}{*}{ Minimum } & Maximum & Mean \pm SE \\
\cline { 2 - 4 } & No. & $\boldsymbol{\%}$ & & & \\
\hline 100 & 33 & 33 & $5.1 \times 10^{3}$ & $1.8 \times 10^{5}$ & $3.8 \times 10^{4} \pm 8.2 \times 10^{3}$ \\
\hline
\end{tabular}

Table (2): Incidence of mold genera inthe examined frozen liver samples.

\begin{tabular}{|c|c|c|}
\hline \multirow{2}{*}{ Mold genera } & \multicolumn{2}{|c|}{ Positive samples } \\
\cline { 2 - 3 } & No. & \% \\
\hline Asperigullus & 18 & 54.55 \\
\hline Penicillium & 17 & 51.52 \\
\hline Thamnidium & 10 & 30.30 \\
\hline Cladosporium & 10 & 30.3 \\
\hline Mucor & 4 & 12.12 \\
\hline Rhizopus & 4 & 12.12 \\
\hline Fusarium & 3 & 9.09 \\
\hline Nigrospora & 1 & 3.03 \\
\hline Trichothecium & 1 & 3.03 \\
\hline
\end{tabular}

Table (3): Incidence of Aspergillus species in examined frozen liver samples.

\begin{tabular}{|c|c|c|}
\hline \multirow{2}{*}{ Asperigillus species } & \multicolumn{2}{|c|}{ Positive samples } \\
\cline { 2 - 3 } & No. & \% \\
\hline A.flavus & 10 & 55.56 \\
\hline A.niger & 8 & 44.45 \\
\hline A.fumigatus & 3 & 16.67 \\
\hline A.terreus & 4 & 22.22 \\
\hline A.ochraceus & 2 & 11.11 \\
\hline A.versicolor & 2 & 11.11 \\
\hline A.nidulans & 1 & 5.56 \\
\hline A.ruber & 1 & 5.56 \\
\hline
\end{tabular}

Table (4): Statistical analytical results of Aflatoxins residues (ppb) in the examined frozen liver samples.

\begin{tabular}{|c|c|c|c|c|c|}
\hline \multirow{2}{*}{ Aflatoxins } & \multicolumn{2}{|c|}{$+\mathbf{v e}$ samples } & \multirow{2}{*}{ Minimum } & \multirow{2}{*}{ Maximum } & \multirow{2}{*}{ Mean $\mathbf{\pm S E}$} \\
\cline { 2 - 3 } & $\mathbf{N o .}$ & $\mathbf{\%}$ & & 41.80 & $23.21 \pm 4.45$ \\
\hline Aflatoxins B1 & 8 & 24.24 & 5.60 & 29.50 & $14.90 \pm 3.36$ \\
\hline Aflatoxins B2 & 7 & 21.21 & 3.20 & 16.10 & $9.11 \pm 1.66$ \\
\hline Aflatoxins G1 & 6 & 18.18 & 4.30 & 8.30 & $4.08 \pm 1.14$ \\
\hline Aflatoxins G2 & 5 & 15.15 & 1.90 & \\
\hline
\end{tabular}

Kafrelsheikh Vet. Med. J. Vol. 15 No. 2 (2017) 


\section{DISCUSSION}

The majority of our animal origin food in Egypt is importedfrom outside to meet the high demand of the increasing population and the high price of meat. These foods may represent dangerous source of some diseases for human health. One of these foods is imported frozen liver which considered an ideal medium for microbial growth.

Table (1) revealed that $33 \%$ of liver samples were contaminated with molds of different species and the total mold count in these liver samples of was ranged from $5.1 \times 10^{3}$ to $1.8 \times 10^{5} \mathrm{cfu} / \mathrm{g}$ with a mean value of $3.8 \times 10^{4} \pm 8.2 \times 10^{3} \mathrm{cfu} / \mathrm{g}$. In previous study, Ashraf (2014) found that the total mold counts in ready to eat liver sandwiches ranged from $1 \times 10^{2}$ to $5 \times 10^{6} \mathrm{cfu} / \mathrm{g}$ with a mean value of $4 \times 10^{5} \mathrm{cfu} / \mathrm{g}$. The presence of mold in the food samples is due to it's dispersing in the form of spores which are abundant in the environment and can be introduced through dust and soil (Apinis, 2003). Their presence in these samples is a serious public health concern as these fungi may be associated with the production of mycotoxins (Makun et al., 2009).

It is evident from the results recorded in table (2)that Aspergillus and Pencillum were the predominant mold genera isolated from positive samples with 54.55 and $51.52 \%$, respectively followed by Cladosporium andThamnidium with the same percent $(30.3 \%)$. The other genera such as Mucor,Rhizopus, Fusarium, Nigrospora, Trichothecium isolated with lower incidence.Further, A.flavus, A. niger, A. fumigatus, A. terreus, A.ochraceus, A. versicolor, A. nidulansand A. ruberwere identified Aspergillus species isolated from the examined imported frozen liver with different percentages as shown in Table (3). 
Contamination of importedfrozen meat and liver with mold spores can be attributed to themishandling of meat from time of their arrival seaport until it reached different retail cold stores asmany investigators mentioned that deep freezing(until $-18^{\circ} \mathrm{C}$ ) has no significant destructive effect uponmold spores as they can resist cold storage (Gill and Lowry, 1982 andMansour et al., 1994).In addition, it is hard to guarantee particularly withhome freezing that the meat will remain safe and ofgood quality for eating but once frozen meat isthawed the microbes come back to life and continuetheir life's work, which is to multiply and consume.

Table (4)declared that $8(24.24 \%), 7(21.21 \%), 6(18.18 \%)$ and 5 $(15.15 \%)$ of the examined frozen liver samples were positive for aflatoxinB1, B2, G1 and G2 residues with a mean concentrations of $23.21 \pm 4.45,14.90 \pm 3.36,9.11 \pm 1.66$ and $4.08 \pm 1.14 \mathrm{mg} / \mathrm{kg}$, respectively. In this respect, Ghada et al. (2017) examined 50 frozen liver samples collected from kafrElsheikh, Egypt and found that $2 \%$ of the examined samples were positive for aflatoxinB1 with concentration of $1.1 \mathrm{mg} / \mathrm{kg}$.

From a good safety point of view, the most remarkable aflatoxin is aflatoxin B1 because it is most prevalent in food and toxic for humans. Aflatoxin residues have been reported in foodproducts including those of animal origins such as liver (Mahmoud et al., 2001). Aflatoxin B1 residues in human food can be dangerous for humans because aflatoxin compounds are heat stable with little degradation and so heating or cooking processes cannot be relied upon to destroy it. 
On the other hand, pressure cooking can reduce the aflatoxin content by $83 \%$ (Park and Kim 2006). As well as ammonia treatment reduces aflatoxin content in animal feed, whereas the contamination of foods of animal origin gets through the diet of the food-producing animals (Apinis, 2003). The European Union has set $2 \mathrm{mg} / \mathrm{kg}$ as the MRL for aflatoxin B1 (Makun et al., 2009), but $0.1 \mathrm{mg} / \mathrm{kg}$ for infants and young children in order to protect the health of this vulnerable population group.

From the results of the present study, it could be concluded that molds and their aflatoxinscontaminated imported frozen liver samples obtained from retail supermarkets in El- Gharbia, Egypt. They could be a potential vehicle for food-borne infections and implementation of preventive measures and consumer food safety education efforts are needed. Proper cooking of liver before consumption and improving personal hygiene to ensure the safety of frozen livers for human consumption.

\section{REFERENCES}

- Association of Official Analytical Chemists "AOAC" (2000): Official Methods of the AOAC International Analysis. 13 $3^{\text {th }}$ Ed., Horwitz. W; (Editor), Academic Press, Washington D.C, USA.

- Anthony, M. H., Ayinla, G. T., Helmina, A. O., Ezekiel, S. A. and Haruna, O. G. (2009). Health implications of toxigenic fungi found in two Nigerian staples: guinea corn and rice. Afr J Food Sci3, 250-256.

- ARX, J.A Vpm (1967).Pilzkunde, J. Cramer inder A.R. Canter Verlag, Kommanditge sellschaft. FL - 9490 Vaduz.

- Apinis, A. (2003). Mycological aspects of storedgrain. Biodeterioration of materials2, 493-498.

- Ashraf M. A. (2014). Microbiological Quality of Ready-to-Eat Liver Sandwiches (Kibda). Global Veterinaria 13 (6), 1097-1102. 
- Bailly, J.-D. and Guerre, P. (2009). Mycotoxins in meat and processed meat products. In Safety of meat and processed meat, pp. 83-124: Springer.

- Darwish, A., Hamdy, M. and Nouman, T. (1986). Quality evaluation of market meat pastes. Vet. Med. J34, 37-48.

- Fazekas, B., Tar, A. and Kovacs, M. (2005). Aflatoxin and ochratoxin A content of spices in Hungary. Food additives and contaminants22, 856-863.

- Galvano, F., Galofaro, V., Ritieni, A., Bognanno, M., De Angelis, A. and Galvano, G. (2001): Survey of the occurrence of aflatoxin M1 in dairy products. Food Additives and Contaminants, 18: 644-646.

- Ghada A.K. Kirrella, Azza M.M. Deeb, R.M. Abdallah(2017). Safety of frozen liver for human consumption.Journal of food and drug a $\mathrm{n}$ a 1 y s i s. In press artice.

- Gill, C. and Lowry, P. (1982). Growth at sub-zero temperatures of black spot fungi from meat. J. Appl. Bacteriol. 52, 245-250.

- Hara, S., Fennel, D., and Hesseltine, C. (1994): Aflatoxin producing strains of $A$. flavus detected by fluorescence of agar medium under U/V light. Appl. Microbiol., 47 (6): 118-123.

- International Commission on Microbiological specification for foods (ICMSF) (1996). Microorganisms in foods 1.Their significance and methods of enumeration. 3rd Ed. Toronto, Univ. of Toronto Press

- Iqbal, S. Z., Asi, M. R. and Jinap, S. (2013). Natural occurrence of aflatoxin B 1 and aflatoxin M 1 in "Halva" and its ingredients. Food Control34, 404-407.

- Kalhy, L. M (2011). Benefits of eating liver our most nutrient-dense food article. Available at: http://blog.radiantlifecatalog.com /bid 126773/Benefits-of-Eating-Liver-Our-Most-Nutrient-Dense-Food. 
- Makun, H.A., T.A. Gbodi, O.H. Akanya, A.E. Salako and G.H. Ogbadu (2009). Health implications of toxigenic fungi found in two Nigerian staples: guinea corn and rice. African Journal of Food Science, 3: 250-256.

- Mahmoud ALE, Sayed AM, Abou-el-Alla AA. (2001). Mycoflora and natural occurrence of mycotoxins in some meat products and livers of poultry and imported bulls. Pak J Biol Sci 4:611e3.

-Mansour, N. K., Yassien, N. A. and El-Sherif, A. M. (1994). Mycoflora of imported frozen beef. Vet. Med. J. Giza42, 89-94.

- Maqbool, U., Ahmad, M., Anwar-ul-Haq and Mohsin Iqbal, M. (2004). Determination of aflatoxin-B1 in poultry feed and its components employing enzyme-linked immunosorbent assay (ELISA). Toxicological \& Environmental Chemistry86, 213-218.

- Park JW, Kim YB. (2006). Effect of pressure cooking on aflatoxin B1 in rice. J Agric Food Chem54:2431e5.

- Raper, K.B. and Fennell, D.I. (1965). The genus Aspergillus. $1^{\text {st }}$ Ed. Williams and Wilkins Company,Baltimore.

- Raper, K.B. and Thom, C. (1969). A manual of the penicillia, Williams and Wilkins Company, Baltimor.

-Samson, R.A. (1979). A complication of Aspergilli. Studies in Mycology 3: 198-202.

-Samson, R.A; Stalk, A. and Hadlok, R. (1976).Revision on the subsection subsection fasiculata of Penicillium and some alliedspecies. Studies in Mycology 2: 75-78.

-Shundo, L. and Sabino, M. (2006): Aflatoxins M1 in milk by immmunoaffinity column cleanup with TLC/HPLC determination. Brazil. J. Micribiol., 37: 164-167.

-Zycha, H.; Siepman, R. and Linnemann, G. (1969). Mucorales Eine Besebreibung alter Gattunger und Arten diesser pilzgruppe ver lag Von. J. Carmer. 
الجودة الفطرية للأكباد المجدة المستوردة للاستهلاك البشري

نظرا لأهمية اللحوم بوصفها مصدرًا غذائًاً مههًاً ، ولنقص هذه اللحوم وارتفاع أسعارها أدبإلى تتـاول الأكباد المجمدة خاصـة المستوردة بوصفها مصدرًا آخر للبروتينـات الحيوانيـة ذات السـعر المنخفض ـ لذلك أُجْرِيَتْ هذه الدراسة على بعض عينات الأكباد المجمدة المستوردة في محافظة الغربية وذلك للتعرف على مدى نلوثها بالفطريات المختلفة وسموم الافلاتوكسين المسببة لبعض الأمـراض الخطيرة للإنسان. لذا فقد تم تجميع عدد 100 عينة ـ وقد أسفرت النتائج عن وجود هذه الفطريات بنسبة 33 \% من العينات ، وكان فطر Aspergillus الفطر السائد بين هذه الفطريات بنسبة 54.55 \% ثم فطر Penicillium بنسبة\%52.52. وقد تم فحص العينات باستخدام جهاز الكروماتوجرافي لمعرفـة مدى تلوثها بالافلاتوكسين ، وَوُجِدَأنّ 24.24، 21.21، 18.18 و 15.15 \% من العينات تحتوي علي

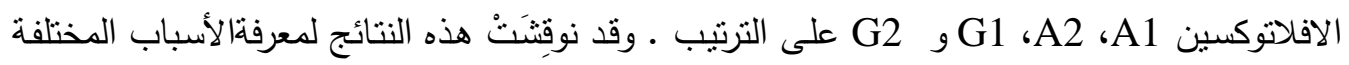
لوجودهذه الفطريات وسمومها بهذه الأكباد والتىى أكَدَتْ عدم اتباع الأساليب الصحية السليمة لتغذية الحيوانات وذبحها للحصول علي أكبادها وذللك للوصول في النهاية لمنتج صحي آمن لضمان سلامة

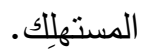

